\title{
シリーズ＼cjkstart新しい内分泌現象
}

\section{成長と摂食行動に関わるホルモンの関係 一成長ホルモンの分泌調節に関わる因子がニワトリヒナの捸食行動に与える影響—}

\author{
橘 哲也 (愛媛大・農) \\ E-mail: tetsu@agr.ehime-u.ac.jp
}

\section{1．脊椎動物の摂食調節と摂食調節因子}

従属栄養生物である動物は体外から栄養素を摂取する、 すなわち損食しなければ生命を維持することはできない。 生命維持だけではなく、より多くの栄養素が必要となる 成長時や繁殖時にも摂食は欠かすことはできない。ただ し、栄養素の過剩摂取は肥満や疾病の原因になるため、 動物には摄食行動を調節するしくみが備わっている。

摂食行動は様々な因子の影響を受ける。それらの因子 には、気温や湿度などの外的因子と、繁殖状態や精神状 態、生理状態なぞの内的因子があり、そ扎らの情報は全 て脳に送られる。例えば、摂食により胃が膨満すると、 その情報が胃の伸展受容器によってキャッチされ、迷走 神経を介して脳に送られる。また、掑食によって血糖值 が上昇すると、脳にある神経細胞が感知して摂食停止の 情報となる。これらの情報は脳によって統合され、最終 的に摄食の開始あるいは停止を決定するが、その際に重 要な役割を果たすのが間脳の視床下部である。

視床下部には弓状核や室傍核、腹内側核、背内側核、 そして外側野といった神経領域があり、各領域に存在し ている神経細胞の活動によって摂食が調節されている。 数十年程前から、それらの神経細胞が分泌する神経伝達 物質が脊椎動物の摂食調節に重要であることが明らかに されてきた。これらの神経伝達物質は「摂食調節因子」 と呼ばれ、肥満の防止や過食症、拒食症などの研究にお いて注目されている。

\section{2. ニワトリヒナにおける摂食調節因子}

家畜であるニワトリにおいても、幼雛期の摂食量がそ の後の成長や生産に影響を与えることから、ヒナの時期 の掑食調節機構の解明が進められている。その成果とし てヒナにおける攝食調節因子の候補物質が多数発見され てきたが(表1)、それらの候補物質の中には噙歯類をは じめとする哺乳類とは異なる作用を示すものが発見され ている。その代表的なものの一つがレプチンである。

肥満遺伝子の産物であるレプチンは、脂肪組織から分 泌されるホルモンとして知られている゙ 。哺乳動物にレ プチンを投与すると、摂食量の減少、エネルギー消費量 の増加、体脂肪組織の減少、さらには体重の減少といっ た変化が生じる。こ扎らの結果に加元、正常なレプチン を産生できない、もしくは正常なレプチン受容体を発現 できないマウスは肥満になることから、レプチンは体脂 肪量抢よび体重調節において重要な働きを持つと言わ机 ている ${ }^{2)}$ 。さらに、レプチンは視床下部に打いて様々な 損食調節因子の作用に影響を与えることが明らかにされ ている。したがってレプチンは単に摂食を抑制するだけ ではなく、末梢からの情報として他の摂食調節の作用を も制御する物質とされている。

ニワトリでもレプチン遺伝子が発見されているが、哺 乳類の研究成果とは対照的に、新生ヒナの脳室内にマ ウスレプチンを投与しても損食量は減少しない3)。これ は、邲化直後のヒナにおける摂食調節機構にはレプチン

表1 これまでに発見されたニワトリヒナにおける摂食調節因子の候補物質

\begin{tabular}{|c|c|c|}
\hline 摂食立進因子 & 摂食抑制因子 & \\
\hline 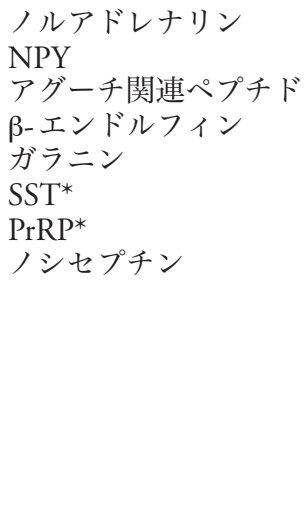 & $\begin{array}{l}\text { セロトニン } \\
\text { ヒスタミン } \\
\text { コレシストキニン } \\
\text { ガストリン } \\
\text { ガストリン放出ペプチド } \\
\text { ニューロメジンC } \\
\text { ニューロメジンB } \\
\text { CRH } \\
\text { ウロコルチン3 } \\
\text { ニューロメジンU } \\
\text { ニューロメジンS } \\
\text { アルギニンバソトシン } \\
\text { メソトシン } \\
\text { インスリン } \\
\text { グルカゴン }\end{array}$ & $\begin{array}{l}\text { アミリン } \\
\text { グルカゴン様ペプチド-1 } \\
\text { グルカゴン様ペプチド-2 } \\
\text { オキシントモデュリン } \\
\text { 血管作動性腸ペプチド } \\
\text { PACAP } \\
\text { サブスタンスP } \\
\text { ニューロペプチドK } \\
\text { カルシトニン関連ペプチド } \\
\text { ゼニン } \\
\text { CART } \\
\text { グレリン* } \\
\text { GHRH* }^{*}\end{array}$ \\
\hline
\end{tabular}

\footnotetext{
*哺乳類とは異なる作用を示す摂食調節因子の候補物質
}

略称は以下の通り。NPY：ニューロペプチドY、SST：ソマトスタチン、PrRP：プロラクチン放出ペプチド、CRH：副 腎皮質刺激ホルモン放出ホルモン、PACAP : 下垂体アデニレートシクラーゼ活性化ポリペプチド、CART : コカイン ンフェタミン誘導転写産物、GHRH：成長ホルモン放出ホルモン 
が重要な働きを持たない可能性を示唆している。しかし、 2016年にこれまでに発見されたニワトリレプチン遺伝 子とは異なる別のレプチン遺伝子が発見された ${ }^{4)}$ 。この ニワトリレプチンの作用を調べることで、ヒナにおける レプチンの真の作用が明らかになるだろう。

レプチンの他にも、ヒナに㧍ける作用が哺乳類とは異 なる摂食調節因子がある。興味深いことに、摄食調節因 子のうち摂食を抑制するもの（摂食抑制因子）の作用は ヒナと哺乳類で類似しているものが多いが、摂食を促進 するもの(摂食促進因子)においては顕著である。例えば、 㛃歯類にモチリンやメラニン凝集ホルモンを脳室内投与 すると摂食行動が立進するが、ヒナではそのような効果 は見られない5)。また、同じく縭歯類の摂食行動を元進 するグレリンや成長ホルモン放出ホルモン $(\mathrm{GHRH})$ は、 䛚歯類とは正反対にヒナの摂食を抑制してしまうの。

これらの結果から撕食調節因子の作用は動物種間で異 なること、ニワトリヒナには独自の摂食調節機構が存在 していることが明らかにされつつある。不思議なことに、 ヒナに打いて独自の作用を示す摂食調節因子には成長ホ ルモン $(\mathrm{GH})$ の分泌に関わるものが多い。そこで著者は GHの分泌に関わる摂食調節因子の作用について調べて きた。

\section{3. ニワトリヒナにおけるGHの分泌調節}

成長ホルモンはその名の通り動物の成長を促すホルモ ンであり、主に下垂体前葉から分泌される。この GHの 分泌は視床下部から分泌されるホルモンによって調節さ れており、GHRHによってGHの分泌が促される一方、 ソマトスタチン (SST) によって分泌が抑制される (図1)。 また、ニワトリでは甲状腺刺激ホルモン放出ホルモン (TRH) によっても GHの分泌が促されることが明らか にされている7 。さらに、末梢からの因子として、胃か ら分泌されるグレリンによっても GHの分泌が充進され ることが知られている8)。

哺乳類では、これらのホルモンはGHの分泌を調節す るだけではなく、摂食の調節に関わっていることが報告

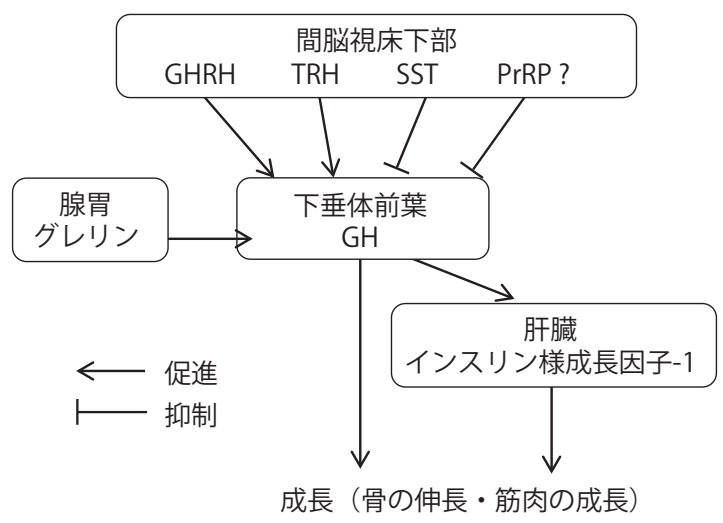

図1 ニワトリヒナにおける GH関連ホルモン 略称は以下の通り。

$\mathrm{GH}$ : 成長ホルモン、GHRH : 成長ホルモン放出ホルモ ン、TRH：甲状腺刺激ホルモン放出ホルモン、SST： ソマトスタチン、PrRP：プロラクチン放出ペプチド
されている。GHの分泌を促すGHRHおよびグレリン は觢歯類の摂食を充進するとされておりり ${ }^{9,10)}$ 、また GH の分泌を抑えるソマトスタチンは摂食を抑えると考元 られている ${ }^{11)}$ 。ヒナでも GHの分泌に関わるホルモンを 中枢投与すると摂食量が変化するが、その変化は䛚歯 類とは明らかに異なる。TRHを例に挙げると、䛚歯類 にTRHを脳室内投与すると摂食が抑制されるが ${ }^{11)}$ 、七 ナに投与しても摂食行動に変化は見られない (未発表)。 なお、TRH以外の GH分泌に関わるホルモンは、ヒナ においてはほぼ一様に哺乳類とは正反対の作用を示す。 これについては次節以降で説明する。

\section{4. ニワトリヒナの摂食調節におけるグレリンの作用}

グレリンは GH分泌を促す $\mathrm{GH}$ secretagogue受容体の 内因性リガンドとして胃から単離されたペプチドホルモ ンであり、 $\mathrm{N}$ 末端側から3番目のアミノ酸残基に脂肪酸 が付加されているという特徵的な構造をもつ。このグレ リンを觢歯類に中枢または末梢投与すると摂食が充進す ることが知られている ${ }^{10)}$ 。グレリンの摂食光進作用はキ ンギョ ${ }^{12)}$ やウシガエル幼生 ${ }^{13)}$ でも見られるため、グレ リンは脊椎動物の摂食を促すと考元られる。

ヒナを12時間絶食させると、哺乳類と同様に血中グ レリン濃度が増加し、腺胃におけるグレリン mRNA発 現量およびグレリン濃度も増加する ${ }^{14)}$ 。食欲が充進する 絶食時にグレリンの合成および分泌量が増加することか ら、ヒナにおいてもグレリンが摂食促進因子として作用 すると考えられる。しかし、ヒナにグレリンを静脈内投 与しても摂食量の変化は見られず15)、さらに脳室内投与 した場合には觢歯類と正反対に摂食が抑制されることが 明らかにされている ${ }^{16)}$ 。このようにヒナの摂食調節にお けるグレリンの作用は畆歯類とは明確に異なる。

觢歯類では、グレリンは視床下部に存在する摂食促進 因子であるニューロペプチドY $(\mathrm{NPY})$ を介して摂食を立 進するが、ヒナにグレリンを脳室内投与してもNPYの mRNA発現量に変化は見ら机ない ${ }^{17)}$ 。その一方で、ヒ ナにグレリンを脳室内投与すると血中コルチコステロン 濃度が増加すること、さらにその作用が摂食抑制因子で もある副腎皮質刺激ホルモン放出ホルモン $(\mathrm{CRH})$ の受 容体アンタゴニストによって緩和されることから、グレ リンはCRHと関係があると考元られる ${ }^{17)}$ 。実際に、グ レリンの摂食抑制作用は CRH受容体アンタゴニストに よって緩和される ${ }^{17)}$ 。以上のことから、ヒナに拈いて は、グレリンは摂食促進作用をもつNPYとは無関係であ り、また摂食抑制作用をもつCRHを活性化させることで、 摂食を抑制すると考えら机ている。このような脳におけ る摂食調節因子のネットワークの違いがヒナと哺乳類に おけるグレリンの摂食に対する作用の違いの原因と考え られている。また、 $\gamma$-アミノ酪酸 (GABA) 受容体、セ口 トニン $2 \mathrm{C}$ 受容体、 $\beta 2$ アドレナリン受容体の各アンタゴ ニストもグレリンの摂食促進作用を部分的に緩和するこ とから、GABAやセロトニン、(ノル)アドレナリンもグ レリンの摂食抑制作用に関与すると考元られている ${ }^{18 \sim 20)}$ 


\section{5. ニワトリヒナの摂食調節におけるGHRHの作用}

哺乳類では、GHRHはその名の通り GHの分泌を促 すホルモンである。一方、ニワトリにおいても GHRH が単離されていたが、哺乳類の GHRHとのアミノ酸配 列の相同性が低いうえ、ニワトリに投与しても GHの分 泌作用がほとんど見られないことから ${ }^{21 ｝ 、 \mathrm{GH} \text { 分泌促進 }$ 因子ではないと考えられていた。ただし、第2番染色体 にあるニワトリ GHRH遺伝子が下垂体アデニレートシ クラーゼ活性化ポリペプチド (PACAP) と同一の遺伝子 によってコードされているのに対し、哺乳類の GHRH はPACAP遺伝子とは全く異なる遺伝子によってコード されているとともに、PACAP遺伝子とは別の染色体に 存在していたこと、さらに GHRH遺伝子の近傍にあ る遺伝子群が哺乳類のそれとはかなり異なっていたこ とから、これまで単離されていたニワトリGHRHは真 のGHRHではないとも考えられていた。哺乳類由来の GHRHをニワトリに投与すると GHの分泌が促される

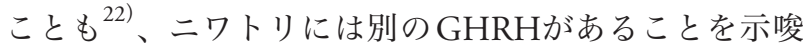
していた。

この仮説は2007年に Wangらがニワトリから既知のも のとは別の新しいGHRHを単離したことで証明される ことになる ${ }^{23)}$ 。Wangらが単離した新しいGHRHの遺伝 子は第20番染色体にあり、その近傍の遺伝子群が哺乳 類のものと類似していた。また、ニワトリに投与すると $\mathrm{GH}$ 分泌が促されたことから ${ }^{24)}$ 、この新しい $\mathrm{GHRH}$ がニワトリの真の GHRHであることが明らかとなった。 そして既知のものは GHRH様ペプチド (GHRH-LP) あ るいはPACAP関連ぺプチド (PRP) と改名されることに なった。その後の研究により、WangらはGHRHおよ びGHRH-LPにはそれぞれ異なる受容体が存在すること、 さらにGHRH-LPは自らの受容体だけではなくGHRH 受容体にも親和性を示すことも明らかにしている ${ }^{25)}$ 。

このGHRH-LPは哺乳類では見られない。それでは、 なぜニワトリに GHRH関連ぺプチドが2つ存在するの だろうか? Wangらは、このGHRHおよびGHRH-LP はニワトリだけではなく両生類や魚類にも見られるこ とから、春椎動物の進化の過程で生じた全ゲノム重複 によって、GHRHの祖先ペプチドが2つに分かれたと推 測している ${ }^{23)}$ 。すなわち、GHRHとGHRH-LPはパラ ログの関係であり、哺乳類の場合、その進化の過程で GHRH-LPが消失したという仮説を提唱している。

GHRH遺伝子から推定されたニワトリGHRHは47 個のアミノ酸残基からなり、 $\mathrm{N}$ 末端から 28～30番目 のアミノ酸残基がグリシンーリジンーアルギニンであ つたことから、 $\mathrm{N}$ 末端側の27アミノ酸残基の断片が生 じ、さらにそのC末端がアミド化する可能性が考えられ た。そこで我々はGHRH (1-47)、GHRH (1-27) およ びGHRH (1-27) NH2を合成し、それぞれヒナに脳室内 投与した後の摂食量の変化を調べた。その結果、いずれ の GHRHもヒナの摂食を抑制することが明らかとなっ $た^{26)}$ 。なお、合成した GHRH-LPを投与した場合でも同 様の効果が見られた ${ }^{26)}$ 。踥歯類にGHRHを脳室内投与 すると摂食行動が促進されるため ${ }^{9)}$ 、GHRHの摂食に与
える影響もヒナと縭歯類では正反対であると考えられる。 ただし、in vitroの実験により、高濃度の GHRHは PACAP受容体の1つであるPAC1受容体に結合するこ とが明らかにされている。PACAPはヒナにおける摂食 抑制因子の1つであるため ${ }^{27)}$ 、投与した GHRHあるい はGHRH-LPがPACAP受容体に結合することでヒナの 摂食を抑制した可能性が残る。しかし、GHRHまたは GHRH-LPと同時にPACAP受容体アンタゴニストを投 与してもGHRHおよびGHRH-LPの摂食抑制作用には 何ら変化が見られなかったため ${ }^{26)}$ 、これらのGHRH関 連ペプチドの作用にはPACAP受容体が関与していない と考えられた。また、GHRHおよびGHRH-LPを脳室 内投与しても間脳における CRHの mRNA発現量や血中 コルチコステロン濃度に変化は見られず、また行動の変 化も見られなかったこと、GHRHおよびGHRH-LPの 摂食抑制作用がCRH受容体アンタゴニストによって緩 和されなかったことから、GHRH関連ぺプチドはスト レス反応や睡眠行動の誘発などの行動の変化によって攝 食を抑制したのではないと考えられた。さらに、間脳に おける GHRHの mRNA発現量が絶食によって増加した ことから、内因性の GHRHの合成量が食事条件ととも に変わると考えられる。なお、食欲が増進する絶食時に GHRHの mRNA発現量が増えることはGHRHの摂食 抑制作用と矛盾しているが、同じように摂食を抑制する グレリンと同様の変化でもある。この実験では間脳全体 について調べているため、間脳各部位における GHRH およびGHRH-LPの mRNA発現量を調べていない。in situハイブリダイゼーション法などを用いることで、間 脳各部位における GHRHおよびGHRH-LPの遺伝子発 現量が明らかになり、GHRH関連ぺプチドの摂食抑制 作用を支える神経ネットワークを解明できると考えてい る。

GHRHおよびGHRH-LPの mRNAは末梢組織でも発 現している ${ }^{23)}$ 。そこで、末梢に存在するGHRH関連 ペプチドがヒナの摂食調節に関わっているかについて も調査した。その結果、GHRH (1-47) を腹腔内投与し た場合にはヒナの摂食量が減少したことから、末梢の GHRHも摂食抑制に関わつている可能性を見出した ${ }^{28)}$ 。 㗉歯類ではGHRHを腹腔内投与しても摂食量の変化が 見られない29）。したがって、末梢における GHRHの作 用もヒナと㗉歯類で異なることが明らかとなった。

\section{6. プロラクチン放出ペプチド (PrRP)}

PrRPは下垂体前葉からのプロラクチン (PRL)の分泌 を促すぺプチドとして哺乳類から単離された ${ }^{30)}$ 。PrRP は31個のアミノ酸残基からなるぺプチドと、そのC末 端側20個のアミノ酸残基からなるぺプチドの2種類があ ることが明らかになっている。しかし、その後の研究に より、向下垂体性視床下部因子が投射する部位である正 中隆起外層に PrRP神経終末が投射しないこと ${ }^{31)}$ 、 PRL 分泌作用が弱いことから ${ }^{32)}$ 、現在ではPrRPのPRL分泌 作用は否定的な意見が多い。その一方で、PrRPには GH 分泌抑制作用があることが見出され ${ }^{33)}$ 、さらにPrRPを 
中枢投与すると摂食行動が抑制されるなど34)、PRL分 泌以外の生理作用が注目されている。

ヒナにおいては、哺乳類由来のPrRPを脳室内投与し たところ、䛚歯類とは反対に摂食行動が充進したことか $ら^{35)}$ 、PrRPの作用もヒナと織歯類で異なる可能性が示 唆された。しかし、この時点ではニワトリPrRPは単離 されておらず、ニワトリと哺乳類のPrRPの構造に違い がある可能性があったため、完全に結論が得られない状 況であった。

哺乳類におけるPrRPの発見とほぼ同時期に、フナか ら硬骨魚類の PRL分泌を促すぺプチドが単離された ${ }^{36)}$ 。 このペプチドは20個のアミノ酸残基からなるものであ り、哺乳類PrRPのC末端側20個のアミノ酸配列との間 に高い相同性を有していた。その後の研究によりこのぺ プチドは硬骨魚類におけるPRL分泌に必須であること が明らかにされている ${ }^{37)}$ 。このペプチドは C-RFaと名付 けられたが、実質的には硬骨魚類のP PrRPであると考え られていた。

これらのPrRPの発見の後に、著者らの研究グループ ではニワトリ由来のPrRPの単離に成功した ${ }^{38)}$ 。この $\operatorname{PrRP} 32$ 個のアミノ酸残基からなり、そのC末端側 20 個のアミノ酸残基のみからなるペプチドも存在している ことが明らかとなった。そのC末端側20個のペプチド は硬骨魚類のC-RFa と同一であった。さらに、32個のア ミノ酸残基からなるぺプチドはヒナの GH分泌を抑制す ることも明らかとなった ${ }^{38)}$ 。これらのペプチドをヒナに 脳室内投与したところ、20個のアミノ酸残基からなるぺ プチドはヒナの摂食に影響を与えなかつたものの、32個 のアミノ酸残基からなるぺプチドではヒナの摂食を促進 した ${ }^{38)}$ 。すなわち、ヒナではニワトリ由来のPrRPでも 哺乳類とは反対に摂食六進作用を有することになる。

このニワトリP PrRP遺伝子は第7番染色体にある。シ ンテニー解析をしたところ、ニワトリの PrRP遺伝子の 近傍にある遺伝子群が魚類と類似していたのに対し、哺 乳類のPrRP遺伝子とは一致しなかった。この事実を踏 まえ、Wangらはニワトリと硬骨魚類には2種類の PrRP

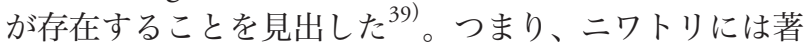
者らの研究グループが単離した PrRPと、哺乳類の PrRP とオーソログである別の PrRPがあることが明らかにさ れたのである ${ }^{39)}$ 。そして、両者は GHRHと同様に全ゲ ノム重複で生じたパラログの関係にあると推定している。 ニワトリと同様に硬骨魚類や両生類にも2 種類の PrRPが 存在しており、魚類のC-RFaは著者らが発見したニワ トリPrRPとオーソログの関係にある。なお、哺乳類で
はC-RFaおよびその受容体の遺伝子は発見されておらず、 進化の過程でその機能が失われたのではないかと考えら れている。これらの結果を受けて、著者らはWangらが 発見したものがニワトリのPrRPであり、そのパラログ にあたる著者らが発見したものを PrRP“2”と改称する ことを提案している ${ }^{40)}$ 。

著者らはこれまでにPrRP2がヒナの摂食を元進するこ とを見出しているが、PrRPについても同様の作用を有 していることを見出している (未発表)。今後、PrRPお よびPrRP2のヒナにおける摂食調節機序を明らかにして いく必要がある。

\section{SST}

GHの分泌を抑えるSSTも摂食調節に関わることが明 らかとされている。縭歯類にSSTを脳室内投与すると、 その作用は摂食条件や投与量に依存しており、摂食を抑 制する場合もあれば、促進することもあることが報告さ れている ${ }^{11,41)}$ 。このSSTをヒナに脳室内投与すると、実 験条件の違いに関わらず摂食量が増加することを明らか にした ${ }^{42)}$ 。SSTと同様の構造を持ち、SST受容体に結合 するコルチスタチンを脳室内投与した場合でも摂食量の 増加が認められた。したがって、ヒナにおいてSSTが摂 食促進因子として作用すると考えられる。現在のところ、 SSTの受容体として5つのサブタイプが存在することが明 らかにされているが、それぞれのアゴニストを脳室内投 与した後の摂食量について調べたところ、SST2、SST3 およびSST5受容体がヒナにおけるSSTの摂食促進作用に 関わつている可能性があることを見いだしている ${ }^{43)}$ 。ま た、SSTによる摂食促進作用がオピオイド $\mu$ 受容体やア ドレナリン $\alpha 2$ 受容体のアンタゴニストの同時投与によっ て緩和されたことから、SSTの作用にはオピオイド神経 系やノルアドレナリン神経系が関与していると考えてい $ろ^{42)}$ 。

\section{8. おわりに}

本稿では、特に GH分泌に関わるホルモンに注目して、 ニワトリのヒナ独自の摂食調節機構について概説した。 これまで述べてきたように、それらのホルモンが GH分 泌に与える作用はヒナと哺乳類でほぼ同一であるのに対 し、摂食行動に与える影響については異なる作用を示す (表2)。箤歯類では、GH分泌を促すグレリンやGHRH が摂食行動を元進し、GH分泌を抑えるSSTやPrRPが 摂食を抑える。これは、成長には摂食が必要であるとい う観点から考えると理に適つていると言えるだろう。こ

表2 ニワトリヒナと箤歯類におけるGH関連ホルモンがGH分泌および摂食行動に与える影響

\begin{tabular}{lcccc}
\hline \multirow{2}{*}{ GH関連ホルモン } & \multicolumn{2}{c}{ GH分泌に対する作用 } & \multicolumn{2}{c}{ 摂食に対する作用* } \\
\cline { 2 - 5 } & 䛚歯類 & ニワトリヒナ & 彗歯類 & ニワトリヒナ \\
\hline グレリン & $\uparrow$ & $\uparrow$ & $\uparrow$ & $\downarrow$ \\
GHRH & $\uparrow$ & $\uparrow$ & $\uparrow$ & $\downarrow$ \\
PrRP & $\downarrow$ & $\downarrow$ & $\downarrow$ & $\uparrow$ \\
SST & $\downarrow$ & $\downarrow$ & $\uparrow$ & $\uparrow$ \\
\hline
\end{tabular}

*中枢投与した場合の作用を示す。 
れに対し、ヒナでは、グレリンやGHRHが摂食行動を 抑制し、SSTやPrRPが摂食を促すという䠛歯類とは全 く正反対の作用を示しており、成長と摂食の関係性が矛 盾しているように思える。何故、ヒナにおける $\mathrm{GH}$ 分泌 に関わるホルモンの作用が哺乳類と異なるのか、答えは 見つかっていない。ヒナを用いた研究では、各 GH関連 ホルモンを投与した後の短時間の摂食行動のみ観察して いるものがほとんどであるため、長期的に摂食行動を調 べた場合ではまた違う効果が得られるのかもしれない。

本稿で紹介した GHRHと PrRPに注目すると、いずれ も全ゲノム重複により2種類存在することが近年の研究 で明らかにされた。ただし、脊椎動物のうち、哺乳類に おいてはいずれも1種類しかなく、全ゲノム重複によっ て生じたはずのもう一つの遺伝子は偽遺伝子化したか、 その機能を完全に失っている。したがって、進化の過程 で鳥類が独自の摂食調節機構を獲得したのではなく、哺 乳類が独自の調節機構を獲得した可能性がある。残念な がら、GH分泌に関するホルモンが鳥類以外の非哺乳類 の脊椎動物の摂食調節機構に与える影響についてはほと んど明らかにされていない。硬骨魚類や両生類など、非 哺乳類の脊椎動物を用いることで、GH分泌に関するホ ルモンと、春椎動物の摂食行動の関係性がより明確に解 明されることを期待している。

\section{文 献}

1 ) Zhang Y et al. Nature, 372, 425-432 (1994).

2 ) Friedman JM et al. Nature, 395, 763-770 (1998).

3 ) Bungo $T$ et al. Brain Res, 817, 196-198 (1999).

4 ) Seroussi E et al. Endocrinology, 157, 737-751 (2016).

5 ) Ando R et al. Br Poult Sci, 41, 508-511 (2000).

$6)$ Furuse M et al. Neurosci Lett, 301, 123-126 (2001).

7 ) Cogburn LA et al. Sturkie's Avian Physiology (Whittow GC edn), pp 635-656 (1999).

8 ) Kaiya $\mathrm{H}$ et al. Endocrinology, 143, 3454-3463 (2002).

9) Vaccarino FJ et al. Nature, 314 167-168 (1985).

10) Kojima M et al. Physiol Rev, 85, 495-522 (2005).
11) Vijayan E et al. Endocrinology, 100, 1727-1730 (1977).

12) Kang KS et al. Peptides, 32, 2242-2247 (2011).

13) Shimizu $S$ et al. Peptides, 51, 74-79 (2014).

14) Kaiya $\mathrm{H}$ et al. Gen Comp Endocrinol, 163, 33-38 (2009).

15) Kaiya $\mathrm{H}$ et al. Domest Anim Endocrinol, 32, 247-259 (2007).

16) Saito ES et al. Eur J Pharmacol, 453, 75-79 (2002).

17) Saito ES et al. Regul Pept, 125, 201-208 (2005).

18) Jonaidi $\mathrm{H}$ et al. Neurosci Lett, 520, 82-86 (2012).

19) Zendehdel $M$ et al. Vet Res Commun, 37, 37-41 (2013).

20) Zendehdel M et al. J Physiol Sci, 64, 383-391 (2014).

21) Harvey $S$. Neural regulation in the vertebrate endocrine system (Prasada Rao PD, Peter RE, eds), pp 69-83 (1999).

22) Peeters $K$ et al. Ann NY Acad Sci, 865, 471-474 (1998).

23) Wang Y et al. Endocrinology, 148, 2405-2416 (2007).

24) Harvey $S$ et al. Gen Comp Endocrinol, 204, 261-266 (2014).

25) Wang $Y$ et al. Domest Anim Endocrinol, 38, 13-31 (2010).

26) Tachibana $T$ et al. Physiol Behav, 139, 195-201 (2015).

27) Tachibana $T$ et al. Neurosci Lett, 339, 203-206 (2003).

28) Tachibana $T$ et al. J Poult Sci, 53, 29-33 (2016).

29) Vaccarino FJ. Ann N Y Acad Sci, 579, 227-232 (1990).

30) Hinuma $S$ et al. Nature, 393, 272-276 (1998).

31) Yamakawa K et al. Neurosci Lett, 267, 113-116 (1999).

32) Samson WK et al. Brain Res, 858, 19-25 (2000).

33) Iijima $N$ et al. Endocrinology, 142, 3239-3243 (2001).

34) Lawrence CB et al. Nat Neurosci, 3, 645-646 (2000).

35) Tachibana $T$ et al. Physiol Behav, 80, 713-719 (2004).

36) Fujimoto $M$ et al. Biochem Biophys Res Commun, 242, 436440 (1998).

37) Fujimoto $M$ et al. Peptides, 27, 1104-1109 (2006).

38) Tachibana $T$ et al. J Neuroendocrinol, 23, 74-81 (2011).

39) Wang Y et al. Endocrinology, 153, 1861-1874 (2012).

40) Tachibana $T$ et al. Front Endocrinol (Lausanne), 5, 170 (2014).

41) Feifel D et al. Brain Res, 535, 189-194 (1990).

42) Tachibana $T$ et al. Gen Comp Endocrinol, 161, 354-359 (2009).

43) Tachibana T et al. Comp Biochem Physiol A Mol Integr Physiol, 158, 47-51 (2011). 